\title{
Decreased Production of Interferon-Gamma by Human Neonatal Cells Intrinsic and Regulatory Deficiencies
}

\author{
Christopher B. Wilson, Judith Westall, Laura Johnston, David B. Lewis, Steven K. Dower, and Alan R. Alpert \\ Division of Infectious Disease, Children's Orthopedic Hospital and Medical Center, and Department of Pediatrics, University of \\ Washington and Immunex Corporation, Seattle, Washington 98105
}

\section{Abstract}

Human neonatal lymphocytes produced little macrophage activation factor in response to mitogens. This correlated with decreased production of interferon-gamma (IFN $\gamma$ ): adult lymphokines contained 894.2 $\pm 177.1 \mathrm{U} / \mathrm{ml}$, whereas neonatal cord and peripheral lymphokines contained $66.9 \pm 17.0$ and $116.7 \pm 29.6$ $\mathrm{U} / \mathrm{ml}$ by bioassay. Results by radioimmunoassay (RIA) for IFN $\gamma$ were similar. In contrast, the interleukin 2 content of cord lymphokines was greater $(P<0.01)$ and that of neonatal peripheral blood lymphokines similar to that of adults. Interleukin 1 production and interleukin 2 receptor expression and affinity were similar for adult and neonatal cells. Interleukins 1 and 2 in amounts comparable to those in adult lymphokines did not increase production of macrophage activation factor or IFN $\gamma$ by neonatal cells. Neonatal cells did not contain intracellular IFN or degrade exogenous IFN. Excess suppressor activity was not found in neonatal cultures. Addition of IFN $\alpha, 10,000-50,000$ $\mathrm{U} / \mathrm{ml}$ of interleukin 2 or phorbol myristate acetate (PMA) to cord mononuclear cells or of adult monocytes or PMA to cord T cells increased IFN $\gamma$ production compared to cells stimulated with concanavalin A (ConA) alone. Nevertheless, under optimal conditions ( $\mathbf{T}$ cells + PMA + Con $\mathbf{A}$ ), adult cells produced much more IFN $\gamma(1,360 \pm 261 \mathrm{U} / \mathrm{ml}$ by RIA) than cord cells $(122 \pm 37$ $\mathrm{U} / \mathrm{ml}$ ). Staphylococcal enterotoxin A (SEA) stimulated cord cell IFN $\gamma$ production at low cell densities; nevertheless, adult cells produced more IFN in response to SEA $(1,341 \pm 350 \mathrm{U} / \mathrm{ml})$ than cord cells $(350 \pm 33 \mathrm{U} / \mathrm{ml})$. Decreased production of IFN $\gamma$ by neonatal cells appears to be due both to differences in their intrinsic capacity to produce IFN $\boldsymbol{\gamma}$ and to differences in regulatory mechanisms.

\section{Introduction}

The human fetus and neonate are unusually susceptible to infection with intracellular pathogens resistance to which appears to be mediated at least in part by $\mathrm{T}$ lymphocyte-dependent macrophage activation (1). We previously reported that adult but not neonatal blood mononuclear cells (MC) ${ }^{1}$ produced a factor(s)

Address reprint requests to Dr. Wilson, Division of Infectious Diseases, Children's Orthopedic Hospital and Medical Center, P. O. Box C5371, Seattle, WA 98105. 1985.

Received for publication 5 August 1985 and in revised form 23 October

1. Abbreviations used in this paper: ConA, concanavalin A; FCS, fetal calf serum; FH, Ficoll Hypaque; IFN, interferon; IL-1, IL-2, interleukins 1 and 2; LK, lymphokines; LPS, lipopolysaccharide; MAF, macrophage activation factor, $\mathrm{MC}$, mononuclear cells; $\mathrm{M} \phi$, macrophage, $\mathrm{PGE}_{2}$, prostaglandin $\mathrm{E}_{2}$; PHA, phytohemagglutinin-P; PMA, phorbol myristate acetate; RIA, radioimmunoassay; rIL-2, recombinant interleukin 2.

J. Clin. Invest.

(c) The American Society for Clinical Investigation, Inc.

0021-9738/86/03/0860/08 $\$ 1.00$

Volume 77, March 1986, 860-867 that activated adult and neonatal monocyte-derived and tissue macrophages $(\mathbf{M} \phi)$ to kill or inhibit the replication of the intracellular pathogen, Toxoplasma gondii (2). We and others have found that interferon-gamma (IFN $\gamma$ ) was the critical $\mathbf{M} \phi$ activation factor (MAF) in adult MC culture supernatants, and that purified or recombinant IFN $\gamma$ but not IFN $\alpha$ or $\beta$ were equally effective (2-4). The importance of IFN $\gamma$ in control of Toxoplasma infection is supported by studies in mice. Murine resistance to this infection correlates directly with the amount of IFN $\gamma$ produced by lymphocytes in response to Toxoplasma (5) and passively administered murine IFN $\gamma$ is protective (6). IFN $\gamma$ may also be important in mediating resistance to viral infection and tumors (7). Consistent with the decreased ability of neonatal MC supernatants to activate $\mathrm{M} \phi$, Bryson et al. (8) and we (2) found that neonatal MC produces less IFN $\gamma$ than adult MC. We have now performed further studies to determine the basis for deficient IFN $\gamma$ production in the neonate. We report that IFN $\gamma$ production by blood MC of neonates is markedly decreased in spite of apparently normal production of interleukin 1 (IL-1), interleukin 2 (IL-2), and IL-2 receptors. Our data suggest that decreased production of IFN $\gamma$ by neonatal $\mathrm{T}$ cells is due both to intrinsic differences in capacity to produce IFN $\gamma$ and to differences in regulatory cell interactions.

\section{Methods}

Reagents. Reagents were obtained from Sigma Chemical Co. (St. Louis, MO) unless otherwise indicated. Hank's balanced salt solution (HBSS), calf serum, L-glutamine, penicillin, and streptomycin were obtained from Gibco (Grand Island, NY). When analyzed by Limulus amebocyte lysate assay (Pyrotell Associates of Cape Cod, Inc., Woods Hole, MA), the RPMI 1640 contained $<0.06 \mathrm{ng} / \mathrm{ml}$ of reference Escherichia coli endotoxin. Fetal calf serum (FCS) was obtained from Sterile Systems, Inc. (Logan UT); FCS contained $<0.003-0.05 \mathrm{ng} / \mathrm{ml}$ endotoxin and lacked detectable $(<1: 4)$ Toxoplasma antibody in the Sabin-Feldman dye test. Concanavalin A (ConA), Ficoll-Hypaque (FH), and Percoll were obtained from Pharmacia Fine Chemicals (Piscataway, NJ) $\left[{ }^{3} \mathrm{H}\right]$ thymidine, Omnifluor, and Aquasol 2 were obtained from New England Nuclear (Boston, MA). Phytohemagglutinin-P (PHA) was obtained from Difco Laboratories (Detroit, MI). Staphylococcal enterotoxin A (SEA) was obtained from Dr. Reginald Bennett, Food and Drug Administration (Washington, DC). Glutaraldehyde was obtained from Ted Pella, Inc. (Irvine, CA). Paraformaldehyde was obtained from J. T. Baker Co., (Phillipsburg, NJ). Diff Quik was obtained from Dade Diagnostics (Aguado, PR). Lymphokwik was obtained from One Lambda, Inc. (Los Angeles, CA).

Partially purified human IFN $\gamma$ (Gg 23-901-530) was obtained from the National Institutes of Health; this preparation was used as a standard to determine the IFN $\gamma$ content of other materials. Recombinant IFN $\gamma$ and monoclonal antibody 12.2067 (IgG1), which neutralizes recombinant and native human IFN $\gamma$, were provided by Genentech, Inc. (S. San Francisco, CA). Purified human IL-2, which lacked detectable IFN, was obtained from Electro Nucleonics, Inc. (Silver Spring, MD); this material contained $6.1 \times 10^{4}$ laboratory units $(\mathrm{U}) / \mathrm{ml}$ of IL-2. Recombinant human IL-2 (rIL-2) was provided by Immunex Corp. (Seattle, WA); this material contained $1.2 \times 10^{6} \mathrm{U} / \mu \mathrm{g}$ and lacked detectable IFN. Reference purified human IL-2, which contained $1.31 \times 10^{7} \mathrm{U} / \mathrm{mg}$, was obtained from the National Institutes of Health. Human IL-1, which was purified from 
supernatants of endotoxin-stimulated monocytes by chromatography on DEAE, was provided by Immunex Corp. (9).

Monoclonal antibodies used to detect $\mathrm{T}$ lymphocytes were CD2 [T,gp50] 9.6, obtained from Dr. J. Hansen, Fred Hutchinson Cancer Research Center, Seattle, WA; CD3 [T,gp 19-20] 64.1, obtained from Genetic Systems Corp. (Seattle, WA); CD8 [T,gp32-33] OKT8, obtained from Ortho Diagnostics (Raritan, NJ). $2 \mathrm{~A} 3$ (IgGl), which recognizes the IL-2 receptor on activated T cells (10), was obtained from Immunex. M21 (IgG1), myeloma protein from the MOPC-21 cell line, was obtained from Litton Bionetics (Kensington, MD) and was used as a control antibody. Fluorescein isothiocyanate labeled $\left(\mathrm{Fab}_{2}^{\prime}\right)$ goat anti-mouse IgG was obtained from Boehringer Ingelheim (La Jolla, CA).

Cell preparations. Blood MC were routinely obtained by $\mathrm{FH}$ density gradient separation of adult or neonatal peripheral blood or neonatal umbilical cord blood as previously described (11). In certain experiments, cells from the FH interface were treated with mononuclear cell Lymphokwik as described by the manufacturer to deplete preparations of contaminating granulocytes and platelets. When $\mathrm{MC}$ were to be used for IL-1 production, cells from the FH interface were washed once in HBSS at $200 \mathrm{~g}$ for $10 \mathrm{~min}$, centrifuged through a cushion of calf serum at $200 \mathrm{~g}$ for $10 \mathrm{~min}$ to decrease platelet contamination, and washed twice in HBSS before use. MC were resuspended in RPMI 1640 containing 2 $\mathrm{mM}$ 1-glutamine, $25 \mathrm{mM}$ HEPES buffer, $50 \mathrm{U} / \mathrm{ml}$ penicillin $\mathrm{G}$ and 50 $\mu \mathrm{g} / \mathrm{ml}$ streptomycin containing $5 \%$ human type AB serum (RPMI $+5 \%$ AS) for MC cultures or $20 \%$ autologous or type AB serum (RPMI $+20 \%$ AS) for preparation of monocyte-M $\phi$ monolayers. The percentage of cells that were monocytes or granulocytes was determined as previously described $(12,13)$. MC suspensions from adult, neonatal cord, and neonatal peripheral blood contained $25.8 \pm 1.6 \%, 19.1 \pm 1.7 \%$, and $11.7 \pm 1.2 \%$ monocytes and $1.0 \pm 0.2 \%, 8.7 \pm 0.9 \%$, and $14.5 \pm 2.4 \%$ granulocytes, respectively. MC suspensions of FH cells isolated after treatment with MC Lymphokwik contained $<2 \%$ granulocytes and less than one platelet per 20 cells.

T lymphocytes were prepared from MC by nylon column adherence (14) followed by incubation of nonadherent cells with $T$ cell Lymphokwik for $45 \mathrm{~min}$ at $37^{\circ} \mathrm{C}$. T cells were then separated from nonviable cells by centrifugation as specified by the manufacturer, washed twice in HBSS and resuspended in RPMI $+5 \%$ AS. Such cell preparations routinely contained $>90 \% \mathrm{~T}$ cells (CD2 or CD3 positive) and $\leq 1 \%$ monocytes.

Monocyte monolayers were prepared in Linbro trays (Linbro Scientific, Hamden CT) as previously described (12). For IL-1 production experiments, the monocyte monolayers were used immediately. For Toxoplasma experiments wells contained $15-\mathrm{mm}$ round glass coverslips and the adherent cells were cultured in vitro for 7-9 $d$ before they were infected, by which time the monocytes had assumed the characteristics of $\mathbf{M} \phi(15)$. Monocyte suspensions were prepared by recovering adherent cells from 100-mm Petri dishes (Corning Glass Works, Corning, NY) after incubation in phosphate-buffered saline, pH 7.4 (PBS), containing $2 \mathrm{mM}$ EDTA at $4^{\circ} \mathrm{C}$ for $15 \mathrm{~min}$ and gently resuspending them with a rubber policeman; these suspensions were routinely $>85 \%$ monocytes.

Preparation of lymphokines $(L K)$. LK were the supernatants of cells $\left(5 \times 10^{6} / \mathrm{ml}\right)$ cultured at $37^{\circ} \mathrm{C}$ in the presence of optimal concentrations of ConA (20-50 $\mu \mathrm{g} / \mathrm{ml})$, PHA (10-40 $\mu \mathrm{g} / \mathrm{ml})$, or SEA $(0.1-0.2 \mu \mathrm{g} / \mathrm{ml})$. Optimal concentration ranges were determined in preliminary experiments. Where indicated, phorbol myristate acetate (PMA) was added in a concentration determined to be optimal for IFN $\gamma$ production $(50 \mathrm{ng} /$ $\mathrm{ml}$ ). Culture supernatants were collected $24 \mathrm{~h}$ later unless otherwise indicated. As indicated in the results, certain cultures were supplemented with IL-1 $(100 \mathrm{U} / \mathrm{ml})$ or IL-2 in the indicated concentrations at the time cultures were initiated. Lymphocyte transformation in response to the same stimuli was assessed as previously described (11).

$I L-1$ production. Lipopolysaccharide (LPS) from $E$. coli $026: \mathrm{B} 26$ was added to monolayers of freshly isolated blood monocytes at a final concentration of $10 \mu \mathrm{g} / \mathrm{ml}$. After incubation for $24 \mathrm{~h}$ culture supernatants were harvested and stored at $-70^{\circ} \mathrm{C}$ until assayed. To determine numbers of adherent cells, monolayers were lysed by the addition of a $1 \%$ cetyltrimethylammonium bromide-napthol blue black solution as described by Nakagawara and Nathan (16), and nuclei were counted in a hema- cytometer. In preliminary experiments addition of indomethacin or dialysis of supernatants before they were assayed were found not to affect the results.

$I L-1$ assay. The IL- 1 content of culture supernatants and reagents was determined by the capacity to stimulate the proliferation of mouse thymocytes in the presence of a suboptimal concentration $(1 \mu \mathrm{g} / \mathrm{ml})$ of PHA, as described by Mizel (17). Thymocytes were obtained from 2-6wk-old $\mathrm{C} 3 \mathrm{H} / \mathrm{HeN}$ mice, which were obtained from the Seattle Veterans Administration Hospital, or $\mathrm{C} 3 \mathrm{H} / \mathrm{HeJ}$ mice, which were obtained from Jackson Laboratories (Bar Harbor, ME). A standard preparation of purified IL-1 was included in each assay. $1 \mathrm{U} / \mathrm{ml}$ of IL-1 is that which stimulated $50 \%$ of maximal proliferation obtained using partially purified IL-1. Results were comparable with thymocytes from both strains of mice and were pooled.

IL-2 assay. The IL-2 content of culture supernatants and reagents was determined by the capacity to maintain proliferation of murine CTLL-2 cells, as previously described (18). One laboratory unit per milliliter of IL-2 is that which will maintain $2 \times 10^{3}$ CTLL-2 cells at $50 \%$ of maximal proliferation over this time period. $27.8 \pm 11.6$ laboratory units are equal in activity to $1 \mathrm{U}$ of the proposed NIH reference IL-2. A standard preparation of crude rat IL-2 or of purified human IL-2 was used in each assay to determine maximum proliferation (18).

Interferon assays. The interferon content of LK was determined by inhibition of vesicular stomatitis versus plaque formation as described (19), except that human WISH cells were used rather than human fibroblasts. A standard preparation of IFN $\gamma$ was used in each assay and activity is reported in units per milliliter of the NIH reference IFN $\gamma$ standard. The sensitivity of the assay was $\sim 5 \mathrm{U} / \mathrm{ml}$ of IFN $\gamma$ and the lowest dilution assayed was 1:5. For the purposes of data analysis, samples lacking detectable activity were considered to contain $20 \mathrm{U} / \mathrm{ml}$.

We also assayed IFN $\gamma$ by a specific radioimmunoassay (RIA) that detects biologically active but not heat- or acid-inactivated IFN $\gamma(20)$. Under our conditions, this assay detected $\geq 0.5 \mathrm{U} / \mathrm{ml}$ of reference IFN $\gamma$. When adult supernatants $(n=18)$ were assayed in both assays, values in the RIA correlated $(r=0.62, P<0.01)$ with values in the bioassay but were somewhat lower $(453.4 \pm 131.8$ vs. $761.2 \pm 163.7, P<0.05)$.

Toxoplasma assay. $\mathrm{M} \phi$ were processed and survival and replication of Toxoplasma assessed microscopically $(2,15)$.

Assay for IL-2 receptors. MC were cultured as described above for the preparation of LK. After incubation for $24 \mathrm{~h}$ (or at other intervals as indicated), the cells were harvested by centrifugation at $200 \mathrm{~g}$ for 10 min, washed twice with cold $\left(4^{\circ} \mathrm{C}\right) \mathrm{PBS}$, and resuspended in cold PBS containing $1 \%$ bovine serum albumin (BSA) and $0.1 \%$ Na azide (PBS + BSA + azide). Monoclonal antibodies were added in a predetermined optimal concentration for $30 \mathrm{~min}$ at $4^{\circ} \mathrm{C}$, cells were washed twice, and fluorescein isothiocyanate labeled $\left(\mathrm{Fab}_{2}^{\prime}\right)$ goat anti-mouse IgG was added. After incubation for $30 \mathrm{~min}$ at $4^{\circ} \mathrm{C}$, cells were washed twice. For doublelabeling experiments, cells were then incubated with phycoerythrin-conjugated $2 \mathrm{~A} 3$ and washed. Cells were then fixed in $2 \%$ paraformaldehyde in PBS pH 7.0 for $10 \mathrm{~min}$, collected by centrifugation, resuspended in PBS + BSA + azide and analyzed in an EPICS-C fluorescence-activated cell sorter (Coulter Instruments, Hialeah, FL).

rIL-2 was radiolabeled with ${ }^{125}$ I by using the Enzymobead radioiodination reagent (Bio-rad Laboratories, Richmond, CA) as described by the manufacturer and had a specific activity of $1.5 \times 10^{15} \mathrm{cpm} / \mathrm{mmol}$. MC were enriched for $T$ cells by a single nylon column adherence, stimulated with ConA + PMA for $48 \mathrm{~h}$ and then washed free of IL-2 by the method of Robb et al. (21). Specific and nonspecific binding of ${ }^{125} \mathrm{I}-\mathrm{IL}$ 2 was determined and data was analyzed as described (22).

Statistics. The significance of the difference between means was evaluated by two-tailed Student's $t$ test or by paired $t$ test as appropriate. Results are expressed as mean \pm standard error.

\section{Results}

Production of MAF and IFN $\gamma$ by blood MC. As previously reported (2), both LK from ConA-stimulated adult MC and re- 
Table I. Production of MAF and IFN by ConA-stimulated Blood MC

\begin{tabular}{|c|c|c|c|c|c|}
\hline \multirow[b]{2}{*}{ Culture } & \multicolumn{2}{|l|}{ M $\phi$ activation } & \multirow[b]{2}{*}{$n$} & \multirow[b]{2}{*}{ Interferon } & \multirow[b]{2}{*}{$n$} \\
\hline & M $\phi$ infected & Toxoplasma/vacuole & & & \\
\hline & \% & & & $U / m l \ddagger$ & \\
\hline \multicolumn{6}{|l|}{ ConA-stimulated LK§ } \\
\hline Adult & $35.7 \pm 2.4^{11 \pi}$ & $60.2 \pm 6.8^{\prime \prime}$ & 6 & $894.2 \pm 177.11$ & 23 \\
\hline Neonatal cord & $114.3 \pm 14.2$ & $91.0 \pm 7.5$ & 4 & $66.9 \pm 17.0$ & 24 \\
\hline Neonatal peripheral & $87.3 \pm 8.3$ & $102.0 \pm 7.6$ & 3 & $116.7 \pm 29.6$ & 10 \\
\hline
\end{tabular}

\begin{abstract}
* Results are expressed as percent of the concomitant control values $20 \mathrm{~h}$ after infection, which were $38.0 \pm 8.6 \%$ infected $\mathrm{M} \phi$ and $5.2 \pm 0.2 \mathrm{Toxa}$ plasma per vacuole. Values at $1 \mathrm{~h}$ after infection were $51.3 \pm 9.0 \%$ infected $\mathrm{M} \phi,<1.2$ Toxoplasma per vacuole and $2.0 \pm 0.2$ Toxoplasma per infected $M \phi$. The $M \phi$ were derived by culturing adult monocytes in vitro for 6-8 d. ₹ Bioassay (see Methods for details). § Supernatants of ConA-stimulated MC cultures harvested at $24 \mathrm{~h}$. " $P<0.05$ vs. controls without $\mathrm{LK}$ and neonatal cord and peripheral LK. I $P<0.001$ vs. neonatal cord and peripheral LK.
\end{abstract}

combinant IFN $\gamma$ enhanced the anti-Toxoplasma activity of adult monocyte-derived $M \phi$; this was indicated by a decrease in the percentage of infected $M \phi$ and a decrease in the mean number of Toxoplasma per vacuole $20 \mathrm{~h}$ after infection (Table I). In contrast, LK from ConA-stimulated neonatal cord or peripheral blood (Table I) or from unstimulated adult MC did not enhance M $\phi$ anti-Toxoplasma activity.

The ability of LK to enhance Toxoplasma activity (MAF activity) correlated with IFN content. Adult LK contained 894.2 $\pm 177.1 \mathrm{U} / \mathrm{ml}$ IFN by bioassay (Table I). In contrast, neonatal cord and peripheral blood MC LK contained 66.9 17.0 and $116.7 \pm 29.6 \mathrm{U} / \mathrm{ml}$, respectively. 1 of 23 adult, 15 of 24 neonatal cord, and 3 of 10 neonatal peripheral LK contained $\leq 20$ $\mathrm{U} / \mathrm{ml}$. Comparable results were obtained when PHA was used as the stimulus instead of ConA.

Relationship of IFN $\gamma$ production to IL-1 and IL-2 production and $I L-2$ receptor expression. In contrast to the decreased production of IFN $\gamma$ and MAF by neonate MC, replication of these cells in response to Con $A$, as indicated by $\left[{ }^{3} \mathrm{H}\right]$ thymidine incorporation, was similar to that by adult MC (Table II). IL-2 production by neonatal cord blood MC was significantly greater and that by neonatal peripheral blood MC was similar to that by adult MC. Similarly, production of IL-1, which is thought to be necessary both for induction of (23) and response to (24) IL2 by $T$ cells, by LPS-stimulated adult and neonatal cord and peripheral blood adherent monocytes (Table III) and MC in suspension (not shown) was similar. Unstimulated cells did not produce detectable IL-1. Further, although addition of purified IL-1 to ConA-stimulated neonatal peripheral blood MC cul- tures slightly but not significantly enhanced IL-2 production (1126 $\pm 769 \mathrm{U} / \mathrm{ml}, n=6$ ) compared to controls (531 \pm 162$)$, MAF activity was not enhanced. IL-1 supplementation did not increase production of IL-2 or MAF by adult or cord blood MC. Similarly, addition of $2,000 \mathrm{U} / \mathrm{ml}$ of rIL-2 (Table IV) or purified IL-2 (not shown) to ConA-stimulated adult or neonatal MC cultures did not increase IFN or MAF production.

As shown in a representative two-color fluorescence experiment (Fig. 1), nearly all ( $>90 \%$ ) of ConA-stimulated adult and neonatal peripheral blood $T$ cells bound anti-IL-2 receptor antibody. Results with neonatal cord blood MC were similar. 2A3 binding to unstimulated MC was similar to that of control M21 myeloma protein. The percentage of MC that were $\mathrm{T}$ cells, as determined by staining with a monoclonal antibody to the $\mathrm{E}$ rosette receptor (CD2), were also similar in six experiments: adult $=62.3 \pm 9.4 \%$, cord $=71.1 \pm 13.0 \%$, and neonatal peripheral $=50.3 \pm 8.6 \%$, respectively.

As determined by binding of ${ }^{125} \mathrm{I}$-rIL-2, adult and neonatal T cells $(n=2)$ had similar numbers of low-affinity $\left(K_{d} \sim 2\right.$ $\left.\times 10^{-7} \mathrm{M}\right)$ IL-2 receptors $\left(1.5-5.3 \times 10^{4} / \mathrm{T}\right.$ cell and 3.6-4.6 $\times 10^{4} / \mathrm{T}$ cell, respectively) and high-affinity $\left(K_{d} \sim 5 \times 10^{-10} \mathrm{M}\right)$ IL-2 receptors $(1,053-1,566$ per $\mathrm{T}$ cell and $923-1,818$ per $\mathrm{T}$ cell, respectively).

Mechanisms for decreased IFNy production in spite of IL2 production by neonatal $M C$. To determine whether there might be a trivial explanation for decreased IFN $\gamma$ production by neonatal MC, we performed a series of experiments: $(a)$ Because, as reported by others (25), FH-separated neonatal cord and peripheral blood MC but not adult MC were contaminated by

Table II. Lymphocyte Transformation and IL-2 Production by MC

\begin{tabular}{|c|c|c|c|c|c|}
\hline & \multicolumn{3}{|c|}{ Lymphocyte transformation } & \multicolumn{2}{|l|}{ IL-2 } \\
\hline & $n$ & Unstimulated & ConA & Unstimulated & ConA \\
\hline & & $c p m$ & $c p m$ & $U / m l$ & $U / m l$ \\
\hline Adult & 38 & $978 \pm 177^{*}$ & $67,692 \pm 4,052$ & $<20$ & $848.3 \pm 129.4$ \\
\hline Neonatal cord & 32 & $4,055 \pm 645$ & $59,209 \pm 5,534$ & $<20$ & $1462.8 \pm 197.3 \ddagger$ \\
\hline Neonatal peripheral & 21 & $1,178 \pm 197$ & $54,869 \pm 8,110$ & $<20$ & $531.2 \pm 161.9$ \\
\hline
\end{tabular}

\footnotetext{
$*$ Mean \pm SE.

$\ddagger P<0.01$ compared to adult, $P<0.005$ compared to neonatal peripheral.
} 
Table III. IL-1 Production by LPS-stimulated Monocytes

\begin{tabular}{llr} 
& $n$ & IL-1 \\
\hline & & $U / m l$ \\
Adult & 9 & $495 \pm 213^{*}$ \\
Neonatal cord & 8 & $880 \pm 332$ \\
Neonatal peripheral & 3 & $1,632 \pm 639$ \\
\hline
\end{tabular}

* Mean \pm SE.

$\sim 10 \%$ granulocytes and each had some platelet contamination (adult more than neonatal), we depleted MC of granulocytes and platelets with monoclonal antibodies and complement; this did not affect results in that IFN production by neonatal cells (cord and peripheral) was $105 \pm 34 \%$ of controls $(n=8)$. (b) To determine whether neonatal MC might degrade IFN $\gamma$, we added $1,000 \mathrm{U} / \mathrm{ml}$ of rIFN $\gamma$ to cultures at the time they were initiated; $2,562 \pm 926 \mathrm{U}(n=2)$ were recovered from adult MC cultures and $1,160 \pm 320 \mathrm{U}(n=3)$ were recovered from neonatal MC cultures. $(c)$ To determine whether neonatal MC produced but did not secrete IFN, we washed $\mathrm{MC}$ and then assayed MC $\left(10^{7}\right.$ cells) sonicates for IFN activity; adult MC contained $125 \pm 55 \mathrm{U}$ whereas neonatal cells did not contain detectable IFN $(n=2)$. (d) When IFN $\gamma$ was assayed by a sensitive RIA, results were similar to the bioassay although mean values for each were somewhat lower than by bioassay (adult $=284.1 \pm 53.8$, cord $=12.0 \pm 2.4$, neonatal peripheral $=10.0 \pm 1.4 \mathrm{U} / \mathrm{ml}) .(e) \mathrm{We}$ also assayed 48-h supernatants of ConA-stimulated MC cultures by the RIA; adult MC supernatants contained 336.3 $\pm 163.6 \mathrm{U} / \mathrm{ml}$, whereas cord MC supernatants contained $36.3 \pm 14.9 \mathrm{U} / \mathrm{ml}$.

We performed additional studies to determine whether decreased IFN $\gamma$ production by neonatal MC was intrinsic to the producing cells, due to abnormal regulatory interactions, or both. For these studies we used the IFN $\gamma$ RIA because of its greater sensitivity and its specificity. Because IFN $\gamma$ production by neonatal cord and peripheral blood MC was similar, we performed these studies with cord MC because larger numbers of cells were available.

Cord MC did not have excess suppressive activity, in that IFN $\gamma$ production by adult MC cocultured with an equal number of cord MC was similar to adult MC alone (Table V). Addition of the cyclooxygenase inhibitor indomethacin $(0.5$ or $5 \mu \mathrm{g} / \mathrm{ml})$ at the initiation of the cultures (Table V) or depletion of $\mathrm{T} 8$ cells with antibody and complement (not shown) did not significantly
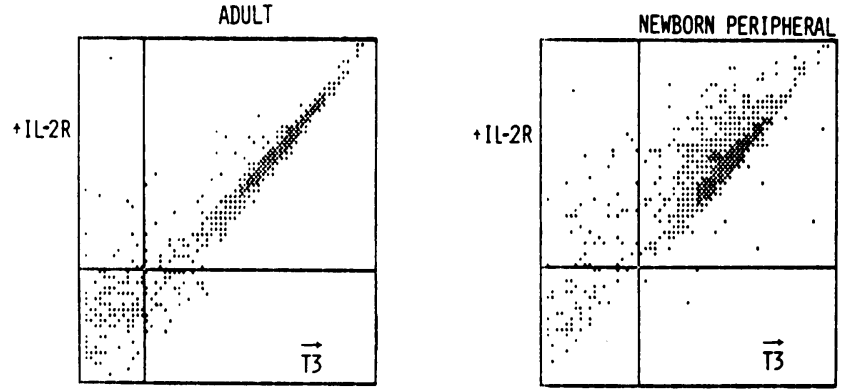

Figure 1. IL-2 receptors on T cells. Two-color fluorescence histogram of $2 \mathrm{~A} 3$ (anti-IL-2 receptor) antibody on the ordinate (IL-2) and CD3, ( $\mathrm{T}$ cell) antibody on the abscissa (T3). This is a representative experiment with adult MC (left) and neonatal peripheral MC (right). $>90 \%$ of adult and neonatal $\mathrm{T}$ cells bound $2 \mathrm{~A} 3$ antibody.

increase IFN $\gamma$ production by cord or by adult MC. The suppressive effect of prostaglandin $\mathrm{E}_{2}\left(\mathrm{PGE}_{2}\right)$ on lymphocyte proliferation in adults (26) and on IFN $\gamma$ production in neonates $(27,28)$ is reported to be abrogated when MC are cultured for $24 \mathrm{~h}$ before stimulation with ConA. However, IFN $\gamma$ production by cord blood MC that were cultured for $24 \mathrm{~h}$ and then stimulated was not different from controls either in 24-h supernatants of standard tube cultures $(6.2 \pm 3.0 \mathrm{U} / \mathrm{ml})$ or in $72-\mathrm{h}$ supernatants of microwell cultures $(9.8 \pm 5.7 \mathrm{U} / \mathrm{ml})$ performed as described by Wakasugi et al. $(27,28)$.

As noted above, IFN recovery from cultures to which 1,000 $\mathrm{U} / \mathrm{ml}$ of IFN $\gamma$ were added was $>100 \%$. Similarly, IFN $\gamma$ production by adult and to a greater extent cord MC was increased in cultures to which $\operatorname{rIFN} \alpha \mathrm{A}(1,000 \mathrm{U} / \mathrm{ml})$ was added at the outset (Table V); addition of rIFN $\alpha \mathrm{A}$ just before supernatants were harvested was without effect (not shown).

We also examined the effects of PMA on IFN $\gamma$ production. PMA can totally replace the monocyte-M $\phi$ requirement for mitogen-stimulated IFN $\gamma$ production and proliferation $(29,30)$. In the presence of PMA, ConA-stimulated cord MC and adult MC produced about six- to eightfold more IFN $\gamma$ than controls (Table IV). When purified $\mathrm{T}$ cells were stimulated with ConA, they produced little IFN $\gamma$ (adult $=9 \pm 6$, cord $=2 \pm 1 \mathrm{U} / \mathrm{ml}$ ). With addition of PMA, ConA-stimulated cord T cells produced $\sim 40$-fold more IFN $\gamma$ than paired MC controls. Nevertheless, under these conditions, cord blood MC produced much less IFN $\gamma(<1-329 \mathrm{U} / \mathrm{ml})$ than adult $\mathrm{T}$ cells $(573-2,359 \mathrm{U} / \mathrm{ml})$. The increase in IFN $\gamma$ production paralleled a comparable increase in IL-2 production. IL-2 production by ConA-stimulated MC

Table IV. Effects of IL-2 on IFN $\gamma$ and MAF Production*

\begin{tabular}{|c|c|c|c|c|c|c|c|c|}
\hline & \multicolumn{3}{|c|}{ IFN $\boldsymbol{\gamma}$} & \multicolumn{5}{|c|}{$\begin{array}{l}\text { MAF } \\
\text { M } \phi \text { infected Toxoplasma/vacuole ( } \% \text { control at } 20 \mathrm{~h} \text { ) }\end{array}$} \\
\hline & $n$ & ConA & ConA + IL-2 & $n$ & ConA & ConA + IL- $2 \ddagger$ & ConA & ConA + IL-2 \\
\hline & & $U / m l$ & $U / m l$ & & $\%$ & $\%$ & $\%$ & $\%$ \\
\hline Adult & 7 & $841.2 \pm 319.3 \S$ & $686.5 \pm 293.1$ & 5 & $35.7 \pm 2.4$ & $44.0 \pm 6.2$ & $60.2 \pm 6.8$ & $60.2 \pm 8.2$ \\
\hline Neonatal cord & 5 & $108.1 \pm 36.3$ & $75.6 \pm 33.2$ & 4 & $114.3 \pm 14.2$ & $160.8 \pm 29.4$ & $91.0 \pm 7.5$ & $99.8 \pm 9.1$ \\
\hline Neonatal peripheral & 5 & $111.7 \pm 41.5$ & $93.0 \pm 23.2$ & 3 & $87.3 \pm 8.3$ & $74.0 \pm 6.6$ & $102.0 \pm 7.6$ & $95.3 \pm 8.4$ \\
\hline
\end{tabular}

* Assays were performed and results are expressed as in Table I. $¥$ Mean \pm SE. $\S 2,000 \mathrm{U} / \mathrm{ml}$ of recombinant IL-2 were added at the time cultures were initiated. Supernatants were harvested $24 \mathrm{~h}$ later. 
Table V. Effects of Different Culture Conditions on IFN $\gamma$ Production in Response to ConA

\begin{tabular}{lcc}
\hline & Adult cells & Cord cells \\
\hline & $U / m l-\%$ control $(n)$ & $U / m l-\%$ control $(n)$ \\
MC & $284 \pm 54-100 \%(26)^{*}$ & $13 \pm 3(19)$ \\
Coculture & $572 \pm 135-94 \%(9)$ \\
+ indomethacin & $127 \pm 41-103 \%(5)$ & $16.6 \pm 9.2-97 \%(8)$ \\
+ IFN $\alpha$ & $170 \pm 66-201 \%(4)$ & $63 \pm 30-780 \%(10)$ \\
+ PMA & $837 \pm 202-678 \%(8)$ & $49 \pm 16-791 \%(13)$ \\
+ IL-2 $(10,000 \mathrm{U} / \mathrm{ml})$ & $136 \pm 68-122 \%(3)$ & $53 \pm 22-1723 \%(3)$ \\
+ IL-2 $(50,000 \mathrm{U} / \mathrm{ml})$ & $277-247 \%(1)$ & $94 \pm 17-4329 \%(3)$ \\
& & \\
T cells & Adult T cells & Cord T cells \\
+ PMA & $1,360 \pm 261-1587 \%(8)$ & $122 \pm 37-4291 \%(6)$ \\
+ adult monocytes $\S$ & $85 \pm 31(5)$ & $61 \pm 19(5)$ \\
+ cord monocytes & $53 \pm 14(5)$ & $15 \pm 10(4)$
\end{tabular}

* Values are mean $\pm \mathrm{SE}$ (number of experiments) units per milliliter of IFN $\gamma$ as determined by RIA followed by the \% of the concomitant response by ConAstimulated MC (\% control).

‡ Equal numbers of adult and cord MC were cultured together.

$\S$ Adult or cord monocytes were added to T cells to equal $10 \%$ of the $\mathrm{T}$ cell concentration.

alone, MC + PMA, and T cells + PMA was 796 $\pm 189,943 \pm 604$, and $13,793 \pm 6,910 \mathrm{U} / \mathrm{ml}$ for adult cells and 1,575 \pm 219 , $17,494 \pm 8,893$, and $18,713 \pm 6,376 \mathrm{U} / \mathrm{ml}$ for cord cells, respectively. Addition of IL-2 to ConA-stimulated cord MC cultures in amounts similar to those detected in ConA + PMA-stimulated cultures produced similar results (Table V), suggesting that the effects of PMA on IFN $\gamma$ production may have been mediated at least in part by increasing IL-2 production $(31,32)$. Although less than that by cord T cells + PMA, IFN $\gamma$ production by purified cord $T$ cells to which adult monocytes (10\%) were added was greater than that by cord $\mathrm{T}$ cells + autologous cord monocytes or that by MC from which the T cells were derived (Table $\mathrm{V})$. In contrast, IFN $\gamma$ production by adult $\mathrm{T}$ cells to which autologous or cord monocytes were added were both less than that by the MC from which the T cells were derived, and markedly less than that by $T$ cells supplemented with PMA.

SEA appears to be the most potent mitogen for stimulating IFN $\gamma$ production by MC (33). T cells appear to be the principal source of SEA stimulated IFN $\gamma(33,34)$. In contrast to ConA and PMA, peak IFN $\gamma$ production in response to SEA occurs later and appears to be partially dependent on cellular proliferation at least under certain culture conditions (34). Wakasugi et al. $(27,28)$ recently reported that SEA was the most effective stimulus for IFN $\gamma$ by neonatal cord MC. We found that, under standard culture conditions (in tubes with $5 \times 10^{6} \mathrm{MC} / \mathrm{ml}$ ), SEA-stimulated cord blood MC produced much less IFN $\gamma$ than adult MC (Table VI). In contrast, 72-h supernatants of cord MC microwell cultures $\left(1 \times 10^{6} \mathrm{MC} / \mathrm{ml}\right)$ contained significantly $(P$ $<0.005$ ) more IFN $\gamma$ than other cord MC culture supernatants. Nevertheless, SEA-stimulated cord MC produced significantly $(P<0.001-0.02)$ less IFN $\gamma$ than SEA-stimulated adult MC under all culture conditions. The 72-h supernatants of ConA-stimulated cord MC microwell cultures contained amounts of IFN $\gamma$ similar to those of 24-48-h supernatants of standard tube cord MC cultures. The IL-2 content and lymphocyte transformation responses of SEA-stimulated cord MC cultures were similar to ConAstimulated cultures (not shown).
Table VI. Production of IFNy in Response to Staphylococcal Enterotoxin $A^{*}$

\begin{tabular}{llll}
\hline & \multicolumn{2}{l}{ Culture conditions } & \\
\cline { 2 - 4 } & Tube & Tube & Microwell \\
& $24 \mathrm{~h}$ & $72 \mathrm{~h}$ & $72 \mathrm{~h}$ \\
\hline & $U / m l(n)$ & $U / m l(n)$ & $U / m l(n)$ \\
Adult MC & $126 \pm 31(5) \ddagger \S$ & $732 \pm 180(3) \S$ & $1,341 \pm 350(2)^{\prime \prime}$ \\
Cord MC & $18 \pm 7(12)$ & $52 \pm 26(6)$ & $350 \pm 33(4)$
\end{tabular}

* Cultures were stimulated with $0.1-0.2 \mu \mathrm{g} / \mathrm{ml}$ SEA for the indicated times. $5 \times 10^{6}$ cells $/ \mathrm{ml}$ were cultured in tubes and $1 \times 10^{6}$ cells $/ \mathrm{ml}$ were cultured in microwells. Results are the maximum units per milliliter IFN $\gamma$ by RIA at either concentration of SEA.

$\ddagger$ Mean \pm SE (number of experiments).

$\S P<0.01$ vs. comparable cord MC cultures.

" $P<0.02$ vs. comparable cord MC cultures.

\section{Discussion}

We previously reported that neither neonatal cord nor peripheral blood LK activated adult or neonatal M $\phi$, and in limited studies, that neonatal cord LK contained less IFN ( $\sim 40 \%$ as much) than adult LK (3). We have now confirmed this difference and have shown it to be of even greater magnitude both by a more reliable bioassay using IFN $\gamma$ standards and by a specific RIA. Neonatal MC both from cord and peripheral blood produced $\sim 10 \%$ as much IFN $\gamma$ as adult MC in response to ConA or PHA. Others have recently reported similarly decreased IFN $\gamma$ production by ConA-, PHA-, or OKT3-stimulated neonatal MC $(8,16,17$, 35). Handzel et al. (36) reported modestly decreased production ( $\sim 60 \%$ of adult) of IFN by PHA-stimulated neonatal MC but did not characterize the type of IFN produced.

We performed a series of studies to examine mechanisms for the decreased production of IFN $\gamma$. A trivial explanation was excluded: granulocytes and platelets, which contaminate neonatal MC, did not inhibit IFN $\gamma$ production; neonatal MC did not degrade exogenous IFN $\gamma$; neonatal MC did not contain intracellular IFN $\gamma$; IFN $\gamma$ was decreased by RIA as well as by bioassay; IFN $\gamma$ production was decreased in response to a range of ConA or PHA concentrations and at 24-72-h after stimulation.

T cells (both T4 and T8) appear to produce most of the IFN $\gamma$ under these conditions $(34,37)$ although NK cells may produce some (38). Production of IFN $\gamma$ by mitogen-stimulated $\mathrm{T}$ cells appears to require interaction with monocytes or $\mathbf{M} \phi$, the production of IL-1 by monocytes, and is linked to IL-2 production and IL-2 receptor expression by the T cells (23). We found that IL-1 production by neonatal monocytes and IL-2 production and receptor expression by neonatal lymphocytes was similar to that by adult cells. To our knowledge, there are no previous reports of IL-1 production by neonatal cells in which activity was assayed by lymphocyte or thymocyte proliferation. Dinarello et al. (39) assayed production of substances pyrogenic for rabbits, which appear to be IL-1 (40), by neonatal cord blood monocytes. They found normal production by cells of neonates born after maternal labor but not by neonates born by Caesarian section without labor. We found no difference in IL-1 production by neonatal cells in the two infants reported here that were born 
without labor compared to those born after labor. The stimulus (LPS) used to induce IL-1 production differed from those used to stimulate IFN $\gamma$ and IL-2 production. It remains possible that IL-1 production by cells from some neonates may be decreased in mitogen-stimulated cultures. However, supplementation of neonatal MC cultures with exogenous IL-1 slightly increased IL2 production but did not affect MAF production, suggesting that decreased IL-1 production was not the cause for decreased IFN $\gamma$ production.

Likewise, under our conditions, IL-2 production by neonatal cord and peripheral MC was similar to or greater than that by adult cells, which is consistent with the results of others with cord MC $(35,41)$. IL-2 receptor antigen expression on ConAstimulated adult and neonatal cord and peripheral $\mathrm{T}$ cells was also similar using the $2 \mathrm{~A} 3$ monoclonal antibody as reported by Yokoi et al. (42) using anti-Tac. Furthermore, the number and $K_{d}$ of high-affinity IL-2 receptors was similar. Proliferation is thought to require binding of IL-2 to high-affinity receptors (22, 23). In contrast to proliferation, IFN $\gamma$ production by $\mathrm{T}$ cells appears to be only partly IL-2 dependent. Under optimal conditions, IL- 2 and IFN $\gamma$ mRNAs are detected at the same time and before detectable product of either appears in the supernatant $(30,43)$ and cycloheximide does not block synthesis either of IL-2 or of IFN $\gamma$ mRNA (43). However, Reem and Ning-Hsing (44) found that addition of anti-Tac inhibited IFN $\gamma$ production by $\sim 25-75 \%$ (44), and we have obtained similar results in preliminary experiments using saturating amounts $(0.2 \mathrm{mg} / \mathrm{ml})$ of IL-2R antibody (2A3) both with adult and cord MC (unpublished observations). Production of IFN $\gamma$ by adult $\mathrm{T}$ cells is enhanced by exogenous IL-2 (50 U) when suboptimal but not optimal ConA concentrations are used (37). Under our conditions, addition of IL-2 in amounts equal to the maximum amounts detectable in ConA-stimulated adult supernatants $(2,000 \mathrm{U} / \mathrm{ml})$ did not increase IFN $\gamma$ production by adult or neonatal MC. Extremely high concentrations of exogenous IL-2 $(10,000-$ $50,000 \mathrm{U} / \mathrm{ml}, \simeq 0.7-3.5 \mathrm{nM}$ ), similar to the concentrations in supernatants of cells stimulated with ConA + PMA, preferentially increased IFN $\gamma$ production by cord MC compared to adult MC in response to ConA. Such concentrations may act by binding to low-affinity IL-2 receptors since high-affinity receptors should be saturated at $<10,000 \mathrm{U} / \mathrm{ml}(21)$. Our data suggest that IFN $\gamma$ production by neonatal cells is selectively deficient and is not primarily due to decreased production or binding of IL-2.

While our studies were in progress, two other groups proposed different mechanisms for decreased IFN $\gamma$ production by neonatal cells. Wakasugi et al. $(27,28)$ suggested that, in contrast to adult cells, neonatal IFN $\gamma$ production $(\sim 4 \mathrm{U} / \mathrm{ml}$ to PHA and ConA, vs. $\sim 150 \mathrm{U} / \mathrm{ml}$ for adults), but apparently not proliferation or IL-2 production, was excessively sensitive to endogenous $\mathrm{PGE}_{2}$ suppression. This was based primarily on the finding that low-dose-irradiated ( 500 rads) but not control neonatal MC produced IFN $\gamma$ that was suppressed by $\mathrm{PGE}_{2}>10^{-10}$ M. However, points of evidence against this being the major mechanism were: $(a)$ the modest effect of indomethacin -8 of 13 neonatal cultures contained increased IFN with indomethacin and the mean IFN $(\sim 20 \mathrm{U} / \mathrm{ml})$ was still much less than by similarly treated adult $\mathrm{MC}(\sim 200 \mathrm{U} / \mathrm{ml}) ;(b)$ that preculturing for $24 \mathrm{~h}$, as a putative mechanism for eliminating $\mathrm{PGE}_{2}$-sensitive cells (26), increased neonatal IFN production slightly (from $\sim 4$ to $80 \mathrm{U} / \mathrm{ml}$ ) but had similar effects on adult cells (from $\sim 150$ to $700 \mathrm{U} / \mathrm{ml}$ ); (c) SEA, a potent stimulus for T cell IFN $\gamma$ pro- duction $(33,34)$, effectively stimulated neonatal IFN $\gamma$ production although $\mathrm{PGE}_{2}$ production was unchanged. We have not found evidence of $\mathrm{PGE}_{2}$-induced suppression because indomethacin (at similar concentrations) and preculturing did not effect IFN $\gamma$ production by neonatal MC. We also did not find evidence of excess suppression of IFN $\gamma$ production by neonatal cells either by coculturing neonatal MC with adult MC or by depleting T8-positive cells from neonatal MC. It is possible that in the studies of Wakasugi's et al. $(27,28)$, irradiation, which increased the neonatal response to $\sim 30 \%$ of the adult response, acted by another mechanism, (e.g., perhaps by affecting regulatory regions of genes for IFN $\gamma$ in neonatal cells) and also induced increased $\mathrm{PGE}_{2}$ sensitivity.

Taylor and Bryson (45) recently reported that neonatal $\mathrm{T}$ cells produced IFN $\gamma$ when adult but not cord blood monocytes that had been cultured in vitro for $7 \mathrm{~d}$ were added; however, the mechanism for this was not further defined. These results differ from those of Wakasugi et al. $(27,28)$, who found that the addition of adult monocytes to neonatal cord MC did not affect IFN $\gamma$ production. We explored this both by supplementing neonatal MC or purified T cells with PMA, which can totally replace monocyte-M $\phi$ requirement for mitogen-stimulated IFN $\gamma$ production $(29,30)$, and by adding adult monocytes to cord $T$ cells. Purified adult T cells + PMA produced 573-2,359 U/ml of IFN $\gamma$, whereas neonatal cells produced $<1-329 \mathrm{U} / \mathrm{ml}$. The amount of IFN $\gamma$ released was higher than reported by Taylor and Bryson $(45)$ or Wakasugi $(27,28)$ and appears to reflect the maximum capacity of $\mathrm{T}$ cells to produce IFN $\gamma$ under these conditions. The data indicate that neonatal IFN $\gamma$ production can be augmented more than that of adults by purification of $T$ cells and addition of PMA, but that the response is still markedly less than that by adult cells. We have also added adult monocytes to neonatal $\mathrm{T}$ cells with results similar to but somewhat lower than with PMA. In contrast, production of IFN $\gamma$ by adult $\mathrm{T}$ cells plus either adult or cord monocytes was less than that by whole MC and similar with cord and adult monocytes. Because these conditions were clearly suboptimal for adult cells but near optimal for neonatal cells, our data are consistent with differences in monocyte regulation of $\mathrm{T}$ cell IFN $\gamma$ production between adult and neonatal cells. Nevertheless, under conditions that stimulated maximally, adult cells produced much more IFN $\gamma$ than neonatal cells. Our data suggest that decreased IFN $\gamma$ (and consequently MAF) production by neonatal $\mathrm{T}$ cells may be both intrinsically limited and diminished by abnormal regulatory interactions. Interestingly, Salahuddin et al. (46) found that none of eight HTLV-1 transformed cord blood T cell lines produced IFN $\gamma$, whereas 9 of 12 adult $T$ cell lines did. This suggests that cells capable of producing IFN $\gamma$ may be decreased in number in neonatal blood.

The ability of SEA to induce IFN $\gamma$ production by neonatal MC in our studies and those of Wakasugi et al. $(27,28)$ is unique and suggests that it may act by a different mechanism or on a different cell population. Others have found that IFN $\gamma$ production by adult $T$ cells in response to SEA peaks later than that in response to ConA or PHA and is also more dependent on proliferation. We found that SEA-stimulated adult cells produced IFN $\gamma$ by $24 \mathrm{~h}$, whereas neonatal cord cells produced little. By $72 \mathrm{~h}$ cord cells in microwells at low cell densities produced $\sim 25 \%$ as much IFN $\gamma$ as adult cells. This may reflect a greater need for cord cells to replicate or differentiate into IFN $\gamma$ producer cells in vitro. Further study of differences in the mechanisms of IFN $\gamma$ 
induction by ConA and SEA in adult and neonatal cells should provide insight into intracellular and intercellular mechanisms of IFN $\gamma$ regulation.

Production of IL- 2 and IFN $\gamma$ by adult T cells appears to be regulated pretranslationally $(43,47)$. However, Salahuddin et al. (46) found that IFN $\gamma$ was regulated posttranslationally in certain HTLV-I-transformed T cell lines. We have recently found that decreased IFN $\gamma$ production by neonatal cells appears to be due to a pretranslational deficiency, since Northern blots of RNA from ConA-stimulated cord MC that were hybridized to an IFN $\gamma$ probe revealed bands that were $<5 \%$ as intense as with RNA from comparable adult cells (48).

IFN $\gamma$ is a much more potent inducer of $\mathrm{M} \phi$ activation than IFN $\alpha$ or $\beta(3,45,49)$. In contrast to IFN $\gamma, \operatorname{IFN} \alpha$, and $\beta$ production by neonatal cells is similar to that by adult cells ( 50 , 51). Thus, decreased production of IFN $\gamma$ may be an important factor that predisposes the neonate to severe infection with intracellular pathogens.

\section{Acknowledgments}

We thank Dr. Reginald Bennett, Food and Drug Administration; Dr. H. Michael Shepherd, Genentech, Dr. Patrick Trown, Hoffman LaRoche, Drs. Paul Conlon and Shirley Kronheim, Immunex, Drs. John Hansen and Patrick Beatty, Fred Hutchinson Cancer Research Center, and Dr. Lyn Goldstein, Genetic Systems, who all provided important reagents; Dr. Christopher Henney, Immunex, for advice and encouragement; and Kae Pierce and Ron Krom for secretarial assistance.

This work was supported by grant HD-18184 and Research Career Development Award AI00568 from the National Institutes of Health, grant R 336-85 to Dr. Wilson from United Cerebral Palsy and grant F32 HD 06706 to Dr. Lewis from the National Institutes of Health.

\section{References}

1. Hahn, H., and S. H. E. Kaufman. 1981. The role of cell-mediated immunity in bacterial infections. Rev. Infect. Dis. 3:1221-1250.

2. Wilson, C. B., and J. E. Haas. 1984. Cellular defenses against Toxoplasma gondii in newborns. J. Clin. Invest. 73:1606-1616.

3. Wilson, C. B., and J. Westall. 1985. Activation of neonatal and adult human macrophages by alpha, beta, and gamma interferons. Infect. Immun. 49:351-356.

4. Nathan, C. F., H. W. Murray, M. E. Wiebe, and B. Y. Rubin. 1983. Identification of interferon- $\gamma$ as the lymphokine that activates human macrophage oxidative metabolism and antimicrobial activity. $J$. Exp. Med. 158:670-689.

5. Shirahata, T., and K. Shimzu. 1980. Production and properties of immune interferon from spleen cell cultures of toxoplasma-infected mice. Microbiol. Immunol. 24:1109-1120.

6. McCabe, R. E., B. J. Luft, and J. S. Remington. 1984. Effect of murine interferon gamma on murine toxoplasmosis. J. Infect. Dis. 150: 961-962.

7. Epstein, L. B. 1979. The comparative biology of immune and classical interferons. In Biology of the Lymphokines. S. Cohen, E. Pich, and J. J. Oppenheim, editors. Academic Press, Inc., New York. 443514.

8. Bryson, Y. J., H. S. Winter, S. E. Gard, T. J. Fischer, and E. R. Stiehm. 1980. Deficiency of immune interferon production by leukocytes of normal newborns. Cell Immunol. 55:191-200.

9. Kronheim, S. R., C. J. March, S. K. Erb, P. J. Conlon, D. Y. Mochizuki, and T. P. Hopp. 1983. Human interleukin 1: purification to homogeneity. J. Exp. Med. 161:490-502.

10. Urdal, D. L., C. J. March, S. Gillis, A. Larsen, and S. K. Dower. 1984. Purification and chemical characterization of the receptor for in- terleukin 2 from activated human $\mathrm{T}$ lymphocytes and from a human Tcell lymphoma cell line. Proc. Natl. Acad. Sci. USA. 81:6481-6485.

11. Wilson, C. B., and J. S. Remington. 1979. Effects of monocytes from human neonates on lymphocyte transformation. Clin. Exp. Immunol. 36:511-520.

12. Wilson, C. B., and J. S. Remington. 1979. Activity of human blood leukocytes against Toxoplasma gondii. J. Infect. Dis. 140:890895.

13. Koski, I. R., D. G. Poplack, and R. M. Blaese. 1976. A nonspecific esterase strain for the identification of monocytes and macrophages. In In Vitro Methods in Cell Mediated and Tumor Immunity. B. R. Bloom, and J. R. David, editors. Academic Press, Inc., New York. 359-362.

14. Miller, W. V., and G. Rodey. 1981. HLA without tears. Educational Products Division, American Society for Clinical Pathology, Chicago, IL. 29-31.

15. Wilson, C. B., V. Tsai, and J. S. Remington. 1980. Failure to trigger the oxidative metabolic burst by normal macrophages. J. Exp. Med. 151:328-346.

16. Nakagawara, A., and C. F. Nathan. 1983. A simple method for counting adherent cells: application to cultured human monocytes, macrophages and multinucleated giant cells. J. Immunol. Methods. 56: 261-268.

17. Mizel, S. B. 1981. Production and quantitation of lymphocyteactivating factor interleukin 1. In Manual of Macrophage Methodology. H. B. Hescowitz, H. T. Holden, J. A. Bellanti, and A. Ghaffar, editors. Marcel Dekker, Inc., New York. 407-416.

18. Gillis, S., M. Ferm, W. Ou, K. Smith. 1978. T-cell growth factor: Parameters of production and a quantitative microassay for activity. $J$. Immunol. 120:2027-2034.

19. Meyers, J. D., R. W. McGuffin, P. E. Neiman, J. W. Singer, and E. D. Thomas. 1980. Toxicity and efficacy of human leukocyte interferon for treatment of cytomegalovirus pneumonia after marrow transplantation. J. Infect. Dis. 141:555-562.

20. Chang, T. W., S. McKinney, V. Liu, P. C. Kung, J. Vilcek, and J. Le. 1984. Use of monoclonal antibodies as sensitive and specific probes for biologically active human $\gamma$-interferon. Proc. Natl. Acad. Sci. USA. 81:5219-5222.

21. Robb, R. J., W. C. Greene, and C. M. Rusk. 1984. Low and high affinity cellular receptors for interleukin 2.J. Exp. Med. 160:1126-1146.

22. Dower, S. K., S. R. Kronheim, C. J. March, P. J. Conlon, T. P. Hopp, S. Gillis, and D. L. Urdal. 1985. Detection and characterization of high affinity plasma membrane receptors for human interleukin $1 . J$. Exp. Med. 162:505-515.

23. Smith, K. A., L. B. Lachman, J. J. Oppenheim, and M. F. Favata. 1980. The functional relationship of the interleukins. J. Exp. Med. 151: 1551-1556.

24. Kaye, J., S. Gillis, S. B. Mizel, E. M. Shevach, T. R. Maleck, C. A. Dinarello, L. B. Lachman, and C. A. Janeway, Jr. 1984. Growth of a cloned helper $\mathrm{T}$ cell line induced by a monoclonal antibody specific for the antigen receptor: interleukin 1 is required for the expression of receptors for interleukin 2. J. Immunol. 133:1339-1345.

25. Arenson, E. B., M. B. Epstein, and R. C. Seeger. 1979. Monocyte subsets in neonates and children. Pediatrics 64(Suppl.):740-744.

26. Goodwin, J. S., and J. Ceuppens. 1983. Regulation of the immune response by prostaglandins. J. Clin. Immunol. 3:295-315.

27. Wakasugi, N., and J.-L. Virelizier. 1985. Defective IFN- $\gamma$ production in the human neonate. J. Immunol. 134:167-171.

28. Wakasugi, N., J.-L. Virelizier, F. Arenzana-Seisdedos, B. Rothhut, J.-M. Mencia Huerta, F. Russo-Marie, and W. Fiers. 1985. Defective IFN $\gamma$ production in the human neonate. J. Immunol. 134:172-176.

29. Rosenstreich, D. L., and S. B. Mizel. 1979. Signal requirements for T lymphocyte activation. J. Immunol. 123:1749-1754.

30. Wiskocil, R., A. Weiss, J. Imboden, R. Kamin-Lewis, and J. Stobo. 1985. Activation of a human $\mathrm{T}$ cell line: a two-stimulus requirement in the pretranslational events involved in the coordinate expression of interleukin 2 and $\gamma$-interferon genes. J. Immunol. 134:1599-1603.

31. Fuller-Farrar, J., M. L. Hilfiker, W. L. Farrar, and J. J. Farrar. 
1981. Phorbol myristic acetate enhances the production of interleukin 2. Cell. Immunol. 58:156-164.

32. Hirano, T., K. Fujimoto, T. Teranishi, N. Nishino, K. Onoue, S. Maeda, and K. Shimada. 1984. Phorbol ester increases the level of interleukin 2 mRNA in mitogen-stimulated human lymphocytes. J. Immunol. 132:2165-2167.

33. Langford, M. P., G. J. Stanton, and H. M. Johnston. 1978. Biological effects of staphylococcal enterotoxin A on human peripheral lymphocytes. Infect. Immun. 22:62-68.

34. Arbeit, R. D., P. L. Leary, and M. J. Levin. 1982. Gamma interferon production by combinations of human peripheral blood lymphocytes, monocytes, and cultured macrophages. Infect. Immun. 35:383390.

35. Miyawaki, T., H. Seki, K. Taga, H. Sato, and N. Taniguchi. 1985. Dissociated production of interleukin-2 and immune $(\gamma)$ interferon by phytohaemagglutinin stimulated lymphocytes in healthy infants. Clin. Exp. Immunol. 50:505-511.

36. Handzel, Z. T., S. Levin, Z. Dolphin, M. Schlessinger, T. Hahn, Y. Altman, B. Schechter, A. Shneyour, and N. Trainin. 1980. Immune competence of newborn lymphocytes. Pediatrics 65:491-496.

37. Kasahara, T., J. J. Hooks, S. F. Dougherty, and J. J. Oppenheim. 1983. Interleukin 2-mediated immune interferon (IFN $\gamma$ ) production by human T cells and T cells subsets. J. Immunol. 130:1784-1789.

38. Kasahara, T., J. Y. Djeu, S. F. Dougherty, and J. J. Oppenheim. 1983. Capacity of human large granular lymphocytes (LGL) to produce multiple lymphokines: interleukin 2 , interferon, and colony stimulating factor. J. Immunol. 131:2379-2385.

39. Dinarello, C. A., M. Shparber, E. F. Kent, Jr., and S. M. Wolff. 1981. Production of leukocytic pyrogen from phagocytes of neonates. J. Infect. Dis. 144:337-343.

40. Dinarello, C. A. 1984. Interleukin-1. Rev. Infect. Dis. 6:51-95.

41. Hayward, A. R., and J. Kurnick. 1981. Newborn T cell suppres- sion: early appearance, maintenance in culture, and lack of growth factor suppression. J. Immunol. 126:50-53.

42. Yokoi, T., T. Miyawaki, A. Yachie, S. Ohzeki, and N. Taniguchi. 1982. Discrepancy in expression ability of Tac antigen and Ia determinants defined by monoclonal antibodies on activated or cultured cord blood T lymphocytes. J. Immunol. 129:1441-1445.

43. Kronke, M., W. J. Leonard, J. M. Depper, and W. C. Greene. 1985. Sequential expression of genes involved in human T lymphocyte growth and differentiation. J. Exp. Med. 161:1593-1598.

44. Reem, G. H., and Y. Ning-Hsing. 1984. Interleukin 2 regulates expression of its receptor and synthesis of gamma interferon by human T lymphocytes. Science (Wash. DC). 225:429-430.

45. Taylor, S., and Y. J. Bryson. 1985. Impaired production of $\gamma$ interferon by newborn cells in vitro is due to a functionally immature macrophage. J. Immunol. 134:1493-1497.

46. Salahuddin, S. Z., P. D. Markham, S. G. Lindner, J. Gootenberg, J. Popovic, H. Hemmi, P. S. Sarin, and R. C. Gallo. 1984. Lymphokine production by cultured human $\mathrm{T}$ cells transformed by human T-cell leukemia-lymphoma virus-I. Science (Wash. DC). 223:703-707.

47. Efrat, S., S. Pilo, and R. Kaempfer. 1982. Kinetics of induction and molecular size of mRNAs encoding human interleukin- 2 and $\gamma$ interferon. Nature 297:236-239.

48. Lewis, D. B., A. Larsen, and C. B. Wilson. 1986. Reduced interferon gamma levels in neonates: evidence for an intrinsic T-cell deficiency independent of other genes involved in T-cell activation. J. Exp. Med. In press.

49. Nathan, C. F., T. J. Prendergast, M. E. Wiebe, E. R. Stanley, E. Platzer, H. G. Remold, K. Welte, B. Y. Rubin, and H. W. Murray. 1984. Activation of human macrophages: comparison of other cytokines with interferon- $\gamma$. J. Exp. Med. 160:600-605.

50. Ray, C. G. 1970. The ontogeny of interferon production by human leukocytes. J. Pediatr. 76:94-98.

51. Ahronheim, G. A. 1979. Toxoplasma gondii: human interferon studies by plaque assay. Proc. Soc. Exp. Biol. Med. 161:522-526. 